\title{
KESALAHAN SISWA SEKOLAH DASAR DALAM MEREPRESENTASIKAN PECAHAN PADA GARIS BILANGAN
}

\author{
Eny Suryowati \\ Dosen Program Studi Pendidikan Matematika STKIP PGRI Jombang \\ E-mail: enysuryowati@gmail.com
}

\begin{abstract}
Fraction is one of the complex material in elementary school. This study aims to describe how students represent fractions on a number line, and describes the mistakes made in the students represent fractions on the number line. This research is qualitative. Subjects in this study there are two students class V of SDN Tamping Mojo II. The data collection method using a task-based interviews. Instruments in this study is the researchers themselves and supporting instruments is a task sheet and interview guidelines. Based on this research, how subjects represent fractions on a number line: fractions with the same denominator on the number line, the subject of linking the amount of parts in the interval of 0 to 1 as the denominator, the subject of linking the amount of the line that divides the interval of 0 to 1 as the denominator, the subject of fractions sort of fractional numerator. Fractions with denominators are not the same on the number line, the subject of fractions with denominators sort biggest, subject to name a point regardless of its parts. Fractions on the number line at a specified point (the same parts and the parts are not the same), the first subject tends to count the number of lines that divide the number line into sections of the same count the number of parts that are formed to be the denominator, the second subject occurs misconceptions with jump number. Fractional mixture on the number line, the two subjects can not represent. Mistakes made by the two subjects are conceptual errors and application errors.
\end{abstract}

Keywords: representation, error, fractions, number line

\section{PENDAHULUAN}

Pecahan merupakan salah satu materi yang dipelajari oleh siswa sekolah dasar. Menurut Mamede dan Oliveira (2011) pecahan merupakan salah satu konsep paling komplek yang harus dipelajari anak selama di sekolah dasar. Menurut Carvalho (2013) bagi siswa, pecahan sulit untuk dipahami. Menurut Charalambous dan Pitta-Pantazi (2007); Kyriakides (2011) dalam mengajar dan belajar matematika, pecahan sudah lama dipandang sebagai salah satu konsep yang paling bermasalah di matematika sekolah dasar. Siswa masih banyak yang mengalami kesulitan ketika belajar pecahan (Behr,1984 dan Kerslake, 1986). Penelitian Mitchell dan 
Horne (2008) menunjukkan adanya miskonsepsi pecahan menggunakan garis bilangan. Hal ini menunjukkan pecahan pada garis bilangan merupakan sesuatu yang sulit untuk dipahami siswa. Hasil penelitian Bright dkk. (1988) tentang cara siswa merepresentasikan pecahan pada garis bilangan dan pengaruh dari pembelajaran pada representasi. Pembelajaran tentang representasi pecahan dan mengurutkan pecahan pada garis bilangan. Hasil tes dan rekaman menunjukkan bahwa bagian-bagian tertentu merupakan sesuatu yang sulit bagi siswa meskipun pembelajaran sudah membantu. Menghubungkan simbol dengan representasi juga terlihat sulit dan tergantung pada pemahaman dari proses membagi-bagi garis bilangan. Penelitian Rose (2011) menunjukkan bahwa siswa kelas lima membuat kesalahan bilangan dalam menjumlahkan dan mengurangi pecahan, termasuk kesalahan konseptual, kesalahan kecerobohan, kesalahan procedural dan kesalahan aplikasi. Hal ini menunjukkan bahwa anakanak sekolah dasar mengalami berbagai kesulitan ketika belajar konsep pecahan.

$$
\text { Pecahan dapat }
$$

direpresentasikan dalam berbagai bentuk, salah satunya dalam garis bilangan. Menurut Bright dkk. (1988) garis bilangan berbeda dengan model lain, panjang menunjukkan satuan dan model garis bilangan tidak hanya menyatakan pengulangan dari satuan tapi juga secara bersama bagian dari semua unit berulang. Garis bilangan dapat diperlakukan sebagai penggaris. Pada garis bilangan tidak ada pemisahan visual antara satuan berurutan. Jadi contoh atau model seluruhnya berkelanjutan. Garis bilangan memberikan fungsi symbol untuk menyampaikan bagian dari arti yang dimaksud. Goldin (2002) menyatakan representasi merupakan suatu bentuk yang dapat mewakili hal lain dalam berbagai cara. Seseorang mengembangkan representasi untuk menginterpretasikan dan mengingat pengalamannya dalam usaha memahami sesuatu. Bruner (1966) menyatakan tiga jenis representasi yaitu enaktif, ikonik dan simbolik. Salkind dan Hjalmarson (2007) menyatakan representasi dari bilangan mencakup objek, aksi, gambar, simbol, dan kata-kata.

Abrahamson (dalam

Salkind dan Hjalmarson, 2006) menjelaskan bahwa representasi matematis merupakan gabungan konsep. Gabungan ide mungkin tersembunyi dalam suatu representasi, dan tidak mudah dipahami oleh siswa. Sebagai hasilnya, siswa dapat menggunakan representasi secara prosedural tanpa pemahaman yang baik. Janvier dkk. (1993) menjelaskan bahwa representasi seperti bilangan, persamaan 
aljabar, grafik, tabel, diagram dan bagan perwujudan eksternal dari konsep matematika sebagai aksi (tindakan) dari rangsangan pada pemahaman yang dalam dan membantu kita memahami konsep. Jadi representasi juga menunjukkan aksi mengungkapkan sesuatu yang di dalam pikiran, merupakan abstraksi mental. Goldin (2002) menyatakan representasi merupakan suatu bentuk yang dapat mewakili hal lain dalam berbagai cara. Seseorang mengembangkan representasi untuk menginterpretasikan dan mengingat pengalamannya dalam usaha memahami sesuatu. Bruner (1966) menyatakan tiga jenis representasi yaitu enaktif, ikonik dan simbolik. Tahap enaktif; dalam tahap ini peserta didik di dalam belajarnya menggunakan atau memanipulasi obyek-obyek secara langsung. Tahap ikonik; pada tahap ini menyatakan bahwa kegiatan anak-anak mulai menyangkut mental yang merupakan gambaran dari objekobjek. Dalam tahap ini, peserta didik tidak memanipulasi langsung objek-objek, melainkan sudah dapat memanipulasi dengan menggunakan gambaran dari objek. Tahap simbolik; tahap ini anak memanipulasi simbol-simbol secara langsung dan tidak ada lagi kaitannya dengan objek-objek. Anak mencapai transisi dari pengguanan penyajian ikonik ke penggunaan penyajian simbolik yang didasarkan pada sistem berpikir abstrak dan lebih fleksibel. Dalam penyajian suatu pengetahuan akan dihubungkan dengan sejumlah informasi yang dapat disimpan dalam pikiran dan diproses untuk mencapai pemahaman

NCTM (2000) representasi digunakan untuk (a). mengorganisir, merekam dan mengkomunikasikan ide matematis, (b). memilih, menerapkan dan mengubah representasi matematis untuk memecahkan masalah, (c). untuk model dan menginterpretasikan fisik, sosial, dan fenomena matematis.

Skemp (1986) menjelaskan secara umum pecahan sering kali dideskripsikan sebagai perbandingan atau hasil bagi dari dua bilangan bulat, $a$ dan $b$, diekspresikan dalam simbol $\mathrm{a} / \mathrm{b}$. Battista (2012) menyatakan pada sekolah dasar, pecahan adalah lambang/simbol dari bentuk $a / b$, dimana $a$ dan $b$ bilangan bulat dan b tidak nol. Wong dan Evans (2007) menjelaskan pecahan senilai adalah satu konsep dalam perluasan skema pecahan. Sebagai contoh himpunan senilai (ekuivalen) dari pecahan $1 / 2$ dapat diwakili seperti $[1 / 2,2 / 4,3 / 6,4 / 8$, ...]. Konsep tersembunyi dari senilai (sebanding) adalah pengetahuan setiap pecahan alam himpunan merupakan sesuatu yang dapat ditukar satu dengan yang lain, Skemp (1986) 
menyatakan dua pecahan dikatakan ekuivalen (senilai) jika mereka mempunyai nilai yang sama.

Representasi pecahan pada garis bilangan,

menggambarkan pecahan $1 / b$ pada garis bilangan dengan menggambarkan interval dari 0 sampai 1 sebagai kesatuan dan dibagi dalam $b$ bagian yang sama. Mengenali bahwa setiap bagian mempunyai ukuran $1 / \mathrm{b}$ dan titik akhir (titik yang ditentukan) dari bagian pada 0 menempatkan bilangan $1 / \mathrm{b}$ pada garis bilangan; (2) menggambarkan pecahan $a / b$ pada garis bilangan dengan memberi tanda pada a panjang $1 / b$ dari 0. Mengenali bahwa hasil interval mempunyai ukuran $\mathrm{a} / \mathrm{b}$ dan titik akhir menempatkan bilangan $\mathrm{a} / \mathrm{b}$ pada garis bilangan (Hsi Wu, 2014)

Representasi

pada

penelitian ini meliputi cara atau strategi siswa merepresentasikan titik pada garis bilangan yang mewakili suatu pecahan :

merepresentasikan pecahan dengan penyebut sama pada garis bilangan, merepresentasikan pecahan dengan penyebut tidak sama pada garis bilangan, merepresentasikan pecahan pada garis bilangan pada titik yang sudah ditentukan (bagianbagiannya sama dan bagianbagiannya tidak sama), merepresentasikan pecahan campuran pada garis bilangan.
Hansen (dalam Rose, 2011) menjelaskan kesalahan sebagai berbuat salah oleh siswa sebagai hasil dari kecerobohan , misinterpretasi dari symbol dan teks, kurangnya pengalaman yang relevan atau kurangnya pengetahuan yang berhubungan dengan suatu topic matematika, belajar sesuai sasaran atau konsep, kurangnya kesadaran atau ketidakmampuan untuk mengecek jawaban yang diberikan. Miskonsepsi membawa (berdampak) pada kesalahan. Drew (dalam Rose, 2011) mendefinisikan miskonsepsi sebagai penyalahgunaan aturan/rumus, suatu generalisasi yang berlebihan atau generalisasi yang kurang atau suatu konsepsi lain dari situasi. Kesalahan yang ditunjukkan karena miskonsepsi siswa tentang suatu topik menandai penafsiran yang salah dari ide matematis sebagai hasil dari pengalaman pribadi siswa atau tidak lengkapnya observasi.

Hodes dan Notling (dalam Rose, 2011) menjelaskan empat jenis kesalahan, yaitu : (1) careless errors, merupakan kesalahan yang dibuat dapat ditangkap secara otomatis meninjau kembali pekerjaan; (2) conceptual errors merupakan kesalahan yang terjadi ketika siswa tidak memahami sifat atau prinsip yang sesuai dalam buku dan pembelajaran; (3) application errors merupakan kesalahan yang dilakukan siswa ketika mereka 
tahu konsep tapi tidak dapat menerapkannya pada situasi atau pertanyaan yang khusus; procedural errors merupakan kesalahan yang terjadi saat melewati petunjuk atau tidak memahami petunjuk tapi menjawab pertanyaan atau masalah.

Berdasarkan penjelasan sebelumnya, bagaimana siswa memahami pecahan pada garis bilangan merupakan sesuatu yang menarik untuk dieksplorasi. Rumusan masalah dalam penelitian ini adalah bagaimanakah siswa merepresentasikan pecahan pada garis bilangan, dan apakah kesalahan-kesalahan siswa dalam merepresentasikan pecahan pada garis bilangan. Tujuan penelitian ini untuk mendeskripsikan cara siswa merepresentasikan pecahan pada garis bilangan, dan untuk mendeskripsikan kesalahankesalahan yang dilakukan siswa dalam merepresentasikan pecahan pada garis bilangan. Hasil penelitian ini diharapkan dapat memberi informasi kepada pembaca terutama guru agar mengetahui bagaimana siswa memahami dan merepresentasikan pecahan pada garis bilangan serta kesalahan-kesalahan yang terjadi dalam merepresentasikan pecahan pada garis bilangan.

\section{METODE PENELITIAN}

Penelitian ini mengungkapkan bagaimana siswa merepresentasikan pecahan pada garis bilangan dengan mendeskripsikan bagaimana cara siswa memberi nama titik pada garis bilangan yang mewakili pecahan, serta memdeskripsikan kesalahan-kesalahan siswa dalam merepresentasikan pecahan pada garis bilangan. Creswell (2012) menyatakan bahwa penelitian yang mempunyai karakteristik sebagai berikut :

1. Belajar tentang pandanganpandangan dari individu;

2. Menilai proses selama penelitian;

3. Melahirkan teori berdasarkan perspektif partisipan/subjek;

4. Mendapatkan informasi detail tentang sedikit orang atau situs penelitian;

Maka penelitian tersebut digolongkan penelitian kualitatif. Ciri utama dari penelitian kualitatif adalah eksplorasi. Berdasarkan kecocokan kriteria tersebut, penelitian ini termasuk penelitian kualitatif.

Subjek penelitian dipilih berdasarkan informasi atau masukan dari guru dan berdasarkan hasil siswa dalam mengerjakan soal yang diberikan peneliti. Metode pengumpulan data menggunakan wawancara berbasis tugas, dimana subjek diminta menjelaskan secara rinci apa yang dikerjakan. Selanjutnya 
dilakukan wawancara, observasi dan dokumnetasi dengan alat perekan. Tugas yang diberikan ke siswa berupa soal tentang pecahan pada garis bilangan. Garis bilangan yang digunakan bervariasi ada yang sudah terbagi dalam beberapa bagian yang sama, ada yang bagiannya tidak sama dan ada yang belum terbagi dalam beberapa bagian. Instrumen penelitian ini adalah peneliti sendiri yang dipandu dengan instrument lembar tugas tentang pecahan pada garis bilangan. Dalam hal ini peneliti merupakan perencana, pelaksana pengumpul data, analisis, penafsir data dan akhirnya menjadi pelapor hasil penelitiannya.

Pengecekan keabsahan data dalam penelitian ini menggunakan triangulasi waktu. Setelah data valid, data akan dianalisis dengan langkahlangkah: (1) menelaah seluruh data yang tersedia dari berbagai cara, yaitu dari wawancara, pengamatan yang sudah dituliskan dalam catatan lapangan, dan hasil mengerjakan tugas;

mengadakan reduksi data dengan membuat abstraksi. Abstraksi merupakan usaha membuat rangkuman yang inti, proses, dan pernyataan-pernyataan yang perlu dijaga untuk tetap didalamnya; (3) menyusun dalam satuan-satuan yang selanjutnya dikategorisasikan; (4) melakukan pemeriksaan keabsahan data; (5) analisis hal yang menarik; dan (6) penafsiran data/kesimpulan.

\section{HASIL PENELITIAN DAN PEMBAHASAN}

Subjek penelitian terdiri dari dua orang (s1 dan s2), subjek diberi tugas kemudian melakukan wawancara. Setelah data dari kedua subjek relatif konsisten maka data valid. Berikut hasil reduksi data dari dua subjek. Strategi siswa dalam merepresentasikan pecahan terlihat pada hasil wawancara berikut :

Subjek pertama (S1)

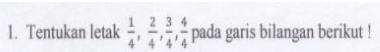

Berikut cuplikan wawancara:

P : "coba ceritakan cara kamu mengerjakan soal no 1 ini !"

S1: " dari yang terkecil"

P : "dari yang terkecil bagaimana maksudnya, ceritakan “

S1: " $1 / 4,1 / 2 \ldots$. .."

$\mathrm{P}$ : " terkecil dari pecahan yang disoal maksudmu?"

S1 : "ya.."

$\mathrm{P}$ : "di soal pecahan terkecilnya berapa?"

S1: " $1 / 4 \ldots$..."

$\mathrm{P}$ : “ kamu bagi jadi berapa bagian?" 
S1: " 4 bagian"

P: "kenapa dibagi menjadi 4 bagian?"

S1: "karen disoalnya dibagi empat ....(sambil menunjuk penyebut pada soal)"

Berdasarkan hasil wawancara dan pekerjaan subjek :

S1 menempatkan pecahanpecahan dari yang terkecil ke yang terbesar(diurutkan pembilangnya). Interval 0 sampai 1 dibagi menjadi empat karena penyebutnya pecahan adalah 4 .

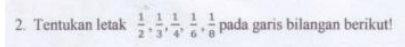

$\longleftarrow$

34

Berikut kutipan wawancara:

P : "coba ceritakan caramu mengerjakan no 2"

S1: "dari yang terkecil"

P : "bagaimana kamu tahu yang terkecil?...caranya bagaimana?"

S1: "disamakan penyebutnya.."

$\mathrm{P}$ : "bagaimana cara menyamakan penyebutnya?"

S1: "yang bisa dibagi 8, 6, 4, 3 dan 2"

P: "berapa?"

S1: "24.."

P : "gimana..?

S1 : "24 dibagi 8 ada 3.....(sambil menulis seperti dilembar tugas)" P : "setelah penyebut disamakan, apa yang kamu lakukan?"

$\mathrm{S} 1$ :.....(diam)

P : "tidak bisa?"
S1: "ya.."

$\mathrm{P}$ : "arti 1/8 menurut kamu bagaimana?...coba kamu gambarkan!"

S1 : “...(menggambar sebuah lingkaran, membagi lingkaran menjadi 8 bagian kemudian 1 bagian diarsir)"

P : "apa arti 1/8 kalau begitu ?..."

S1 : "1 dibagi 8.."

Berdasarkan hasil wawancara dan pekerjaan subjek:

S1 membagi garis bilangan menjadi 12 bagian kemudian menempatkan pecahan-pecahan dari yang terkecil, dengan menyamakan penyebutnya (menjadi 24 karena bisa dibagi 8 , 6, 4, 3 dan 2). Subjek belum bisa menjelaskan maksud (arti) 1/8 pada garis bilangan. Subjek dapat menjelaskan 1/8 dengan menggambarkannya dalam suatu lingkaran dibagi menjadi 8, kemudian 1 bagian diarsir.

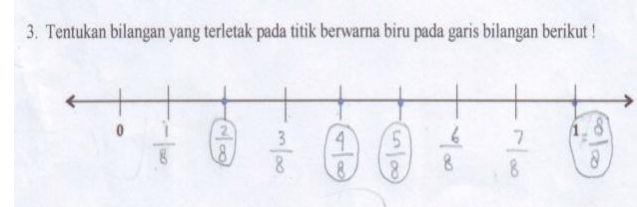

Berikut kutipan wawancara :

$\mathrm{P}$ : "bisa diceritakan caramu mengerjakan soal no 3 ?"

S1: "dihitung garisnya...(garis yang membagi garis bilangan menjadi beberapa bagian)" P : "lalu... setelah kamu hitung ada berapa garisnya?" 
S1 : "ada 8.."

P : "lalu...coba gimana kamu menghitungnya?"

S1 : "(sambil menunjuk pada garis bilangan, dihitung garis setelah nol)....lalu dijadikan penyebut.."

P : "kemudian ?.."

S1 : "diberi nama titiknya mulai dari $1 / 8$ sampai $8 / 8$ ...(melingkari pecahan pada titik berwarna biru"

P : "apakah bagian-bagian dalam garis bilangan itu sama?"

S1: "ya..."

P : "jadi titik warna biru mewakili bilangan berapa?"

S1: " $2 / 8,4 / 8,5 / 8,1=8 / 8$ "

Berdasarkan hasil wawancara dan pekerjaan subjek :

S1 menghitung banyaknya garis dimulai setelah 0 , ada 8 garis kemudian 8 dijadikan penyebut. Kemudian setiap titik diberi nama $\frac{1}{8}, \frac{2}{8}, \frac{3}{8}, \frac{4}{8}, \frac{5}{8}, \frac{6}{8}, \frac{7}{8}, \frac{8}{8}$. S1 menandai (melingkari) pecahan pada titik yang berwarna biru. S1 mengetahui bagian-bagian pada garis bilangan tersebut sama.

4. Tentukan bilangan yang terletak pada titik berwarna merah pada garis bilangan berikut!

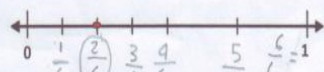

Berikut cuplikan wawancara :

P : "sekarang no 4, titik warna merah kamu tuliskan 2/6...kok bisa itu 2/6, ceritakan!"
S1 : "dihitung garisnya...(garis yang membagi garis bilangan)" P : " ada berapa garisnya?"

S1 : " ada 6 ...(sambil menghitung kembali garis yang membagi garis bilangan mulai dari setelah nol)"

$\mathrm{P}$ : "apakah sama bagianbagiannya itu?"

S1 : "tidak..."

$\mathrm{P}$ : "trus mengapa titik yang merah itu 2/6?"

S1 : "karena bayak garis ada 6 "

Berdasarkan hasil wawancara dan pekerjaan subjek:

S1 menghitung banyaknya garis yang terdapat pada garis bilangan mulai garis setelah nol, terdapat 6 garis. Kemudian memberi nama pada setiap titik pada garis bilangan $\frac{1}{6}, \frac{2}{6}, \frac{3}{6}, \frac{4}{6}, \frac{5}{6}, \frac{6}{6}$.

S1 menyadari kalau bagian-bagian pada garis bilangan tersebut ada yang tidak sama.

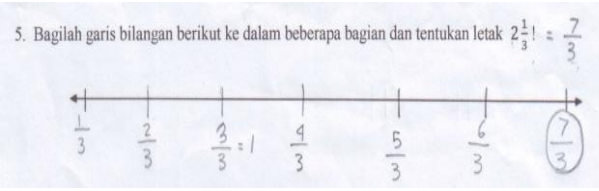

Berikut cuplikan wawancara :

P : "sekarang yang no 5 diceritakan caramu mengerjakannya"

S1 : "dijadikan pecahan biasa"

P : " bagaimana caranya?"

S1 : "3 kali dua trus ditambah 1"

$\mathrm{P}$ : "apa artinya $2 \frac{1}{3}$ ?"

S1 : "artinya 7 dibagi 3" 
P : “ bisa digambarkan 7/3 itu seperti apa?"

S1 : “..(subyek menggambar 7 lingkaran kemudian memberi tanda yang mengelompokkan 2 lingkaran kemudian 1 lingkaran sisanya dibagi tiga)..."

P : "kalau soal ini (no. 5) bagaimana?"

S1 : "garis bilangannya dibagi 7"

P : "trus.."

S1 : " setiap garis yang membagi garis bilangan diberi nama $1 / 3$ sampai $7 / 3$,penyebutnya 3 karena disoal 3"

Berdasarkan hasil wawancara dan pekerjaan subjek :

S1 mengubah pecahan $2 \frac{1}{3}$ menjadi $\frac{7}{3}$, membagi garis bilangan menjadi 7 bagian karena pembilangnya 7 dan penyebutnya 3 karena di soal penyebutnya 3 . S1 memahami maksud $\frac{7}{3}$ dengan menggambarkan seperti di bawah ini :

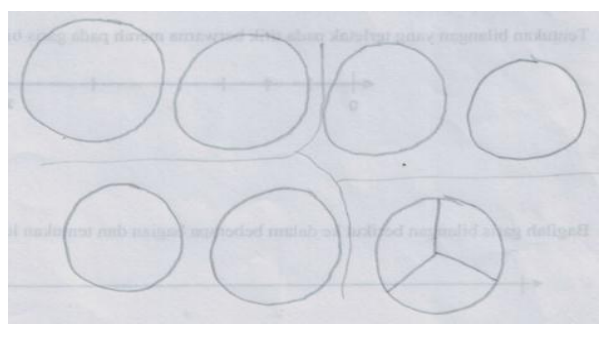

Subjek kedua (S2)

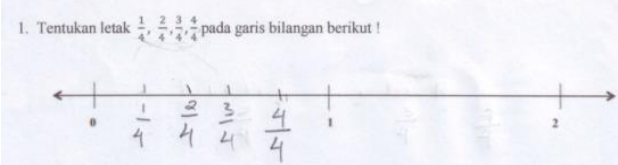

Berikut cuplikan wawancara:

P : "coba ceritakan caramu mengerjakan soal no 1 !"

S2 : "saya pikir itu lompat satu sehingga bisa ditulis $1 / 4$, $2 / 4, \ldots ., 4 / 4$ "

P : "kamu bagi menjadi berapa bagian?"

S2 : "empat.."

P : "mengapa...?"

S2 : "karena penyebutnya empat"

$\mathrm{P}$ : "coba tunjukkan mana empat bagian yang kamu maksud?"

S2 : ....(sambil menghitung banyaknya garis yang sudah dibuat yang membagi interval o sampai 1)...

Berdasarkan hasil wawancara dan pekerjaan subjek :

S2 membuat garis yang membagi antara 0 sampai 1 sebanyak 4 garis karena penyebut pada pecahan 4 . S1 memahami garis bilangan ini sebagai lompat 1 angka setiap bagiannya. Kemudian menempatkan setiap pecahan yang ditentukan pada garis bilangan secara urut dari pembilangnya. Subyek belum memahami bagianbagian dalam garis bilangan (subyek memahami bagian itu sama dengan garis yang membagi garis bilangan menjadi beberapa bagian).

2. Tentukan letak $\frac{1}{2}, \frac{1}{3}, \frac{1}{4}, \frac{1}{6}, \frac{1}{8}$ pada garis bilangan berikut!

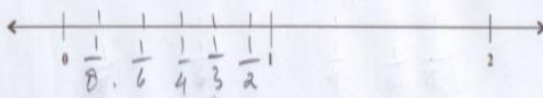


Berikut kutipan wawancara:

P : "caramu bagiamana menentukan letak pecahan itu pada garis bilangan?"

S2 : "dibagi...."

P : "apanya yang dibagi?"

S2 : "penyebutnya..."

P : "lalu?"

S2 : "diurutkan dari penyebut yang terbesar "

P : "mengapa?"

S2 : "em...kalau kecil kan ada 3" ....(sambil menunjuk penyebut 3 pada pecahan $1 / 3$ )

$\mathrm{P}$ : " $1 / 2$ dengan $1 / 4$ itu besar mana?"

S2 : "besar $1 / 2$ "

Berdasarkan hasil wawancara dan pekerjaan subjek : S2 menempatkan pecahan yang ditentukan dari penyebut yang terbesar sampai penyebut yang terkecil. S2 tidak memperhatikan bagian-bagian dalam interval antara 0 dan 1.

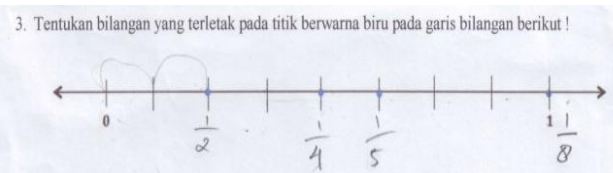

Berikut kutipan wawancara :

P : “yang no 3, mengapa dititik berwarna biru itu kamu tuliskan $1 / 2$ ?"

S2 : "saya rasa itu lompat, seperti waktu di kelas 4 dulu...lompat dua jadi $1 / 2$ “...(sambil menunjukkan lompat dua kali dari nol)
P : “ 2 menunjukkan lompatannya maksudmu begitu?"

S2 : "ya..."

P : "setelah itu...?"

S2 : "selanjutnya lompat dua lagi terus lompat satu, sehingga $1 / 4$ dan $1 / 5$ “

$\mathrm{P}$ : "yang titik biru terakhir itu bilangannya berapa?"

S2 : "1/8.."

$\mathrm{P}$ : "berarti $1 / 8$ itu sama dengan 1?"

S2 : ...(tidak menjawab)

Berdasarkan hasil wawancara dan pekerjaan subjek :

S2 memahami soal no 4 sama seperti bilangan lompat 2 angka dan 1 angka, titik biru pertama lompat 2 angka dari titik nol, 2 menjadi penyebutnya. Kemudian lompat dua lagi sehingga titik biru kedua penyebutnya 4 . Kemudian lompat 1 angka sehingga titik biru yang ketiga penyebutnya 5 .

4. Tentukan bilangan yang terletak pada titik berwarna merah pada garis bilangan berikut!

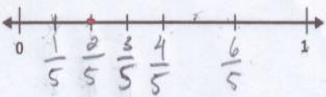

Berikut kutipan wawancara:

P : "titik warna merah kamu tuliskan $2 / 5$, mengapa?"

S2 : "karena ada lima yang kosong pada garis bilangan"

P : "maksudnya?..."

S2 : "ada 5 garis pada garis bilangan yang tidak ada isinya"...(maskudnya tidak ada tulisan angkanya) 
P : "terus.."

S2 : "jadi saya tulis $1 / 5,2 / 5 \ldots$...

$\mathrm{P}$ : "apakah bagian-bagian pada garis bilangan itu semua sama?" S2 : "nggak (tidak)"

Berdasarkan hasil wawancara dan pekerjaan subjek :

S2 menghitung jumlah garis yang kosong (tidak ada bilangannya), ada 5 garis yang belum ada bilangannya. Kemudian 5 menjadi penyebut dan pembilang ditulis mulai dari bilangan 1 sampai 5 .

S2 menyadari bagian-bagian pada garis bilangan tersebut ada yang tidak sama.

5. Bagilah garis bilangan berikut ke dalam beberapa bagian dan tentukan letak $2 \frac{1}{3}$ !

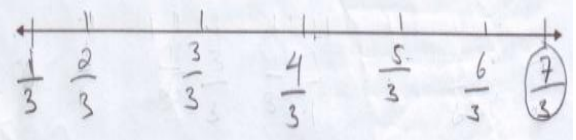

Berikut cuplikan wawancara:

P : " $2 \frac{1}{3}$ kok jadi $7 / 3$ mengapa?"

S2 : "karena $7 / 3$ itu sama dengan $2 \frac{1}{3}$,

P : "maksudnya 7/3 itu apa?"

S2 : “ ada tujuh dibagi 3"...(lalu S2 menggambarkan maksud 7/3dengan menggambar 7 lingakaran yang akan dibagi ke 3 orang)

P : "kalau dituliskan pada garis bilangan seperti apa caramu ?....apakah kamu membagi dulu garis bilangan td?"

S2: "уа.."

P : “ mengapa $1 / 3$ disitu..?"
S2 : "karena saya rasa itu angka yang paling kecil"

$\mathrm{P}$ : "mengapa penyebutnya tiga?"

S2 : "disoalnya penyebutnya juga tiga"

Berdasarkan hasil wawancara dan pekerjaan subjek :

S2 mengubah pecahan $2 \frac{1}{3}$ menjadi $\frac{7}{3}$. Garis bilangannya dibagi (membuat garis yang membagi garis bilangan tersebut sebanyak 7 garis), kemudian tiap garis diberi nama dari $\frac{1}{3}$ sampai $\frac{7}{3}$. S2 memahami arti $\frac{7}{3}$ dengan menggambarkan seperti dibawah ini.

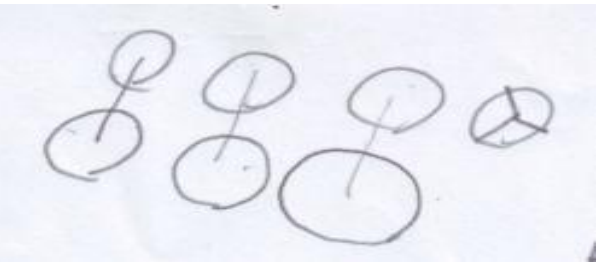

\begin{tabular}{|c|c|c|}
\hline & \multicolumn{2}{|c|}{ Kesalahan } \\
\hline & $\mathrm{S} 1$ & S2 \\
\hline $\begin{array}{l}\text { merepresen } \\
\text { tasikan } \\
\text { pecahan } \\
\text { dengan } \\
\text { penyebut } \\
\text { sama pada } \\
\text { garis } \\
\text { bilangan }\end{array}$ & $\begin{array}{l}\text { Tidak ada } \\
\text { kesalahan }\end{array}$ & $\begin{array}{l}\text { Membagi } \\
\text { garis } \\
\text { bilangan } \\
\text { tidak sesuai } \\
\text { dengan } \\
\text { penyebut } \\
\text { pecahan }\end{array}$ \\
\hline $\begin{array}{l}\text { Merepresen } \\
\text { tasikan } \\
\text { pecahan } \\
\text { dengan } \\
\text { penyebut } \\
\text { tidak sama } \\
\text { pada garis } \\
\text { bilangan }\end{array}$ & $\begin{array}{l}\text { Membagi } \\
\text { garis } \\
\text { bilangan } \\
\text { tidak } \\
\text { sesuai } \\
\text { dengan } \\
\text { penyebut } \\
\text { pecahan }\end{array}$ & $\begin{array}{l}\text { Membagi } \\
\text { garis } \\
\text { bilangan } \\
\text { tidak sesuai } \\
\text { dengan } \\
\text { penyebut } \\
\text { pecahan }\end{array}$ \\
\hline
\end{tabular}




\begin{tabular}{|c|c|c|}
\hline $\begin{array}{l}\text { Merepresen } \\
\text { tasikan } \\
\text { pecahan } \\
\text { pada garis } \\
\text { bilangan } \\
\text { pada titik } \\
\text { yang sudah } \\
\text { ditentukan : } \\
\text { a. Bagian- } \\
\text { bagiann } \\
\text { ya sama } \\
\text { b. Bagian- } \\
\text { bagiann } \\
\text { ya tidak } \\
\text { sama }\end{array}$ & $\begin{array}{l}\text { a. Tidak } \\
\text { ada } \\
\text { kesala } \\
\text { han } \\
\text { b. Tidak } \\
\text { memp } \\
\text { erhati } \\
\text { kan } \\
\text { ukura } \\
\text { n pada } \\
\text { tiap } \\
\text { bagian } \\
\text { pada } \\
\text { garis } \\
\text { bilang } \\
\text { an } \\
\text { (pada } \\
\text { garis } \\
\text { bilang } \\
\text { an ada } \\
\text { bagian } \\
\text { yang } \\
\text { tidak } \\
\text { sama) }\end{array}$ & $\begin{array}{l}\text { a. Menghitu } \\
\text { ng } \\
\text { penyebut } \\
\text { dari } \\
\text { angka nol } \\
\text { b. Menghitu } \\
\text { ng } \\
\text { bagian- } \\
\text { bagian } \\
\text { garis } \\
\text { untuk } \\
\text { pembilan } \\
\text { g dan } \\
\text { penyebut } \\
\text { tidak } \\
\text { secara } \\
\text { keseluruh } \\
\text { an, tidak } \\
\text { memperh } \\
\text { atikan } \\
\text { ukuran } \\
\text { pada tiap } \\
\text { bagian } \\
\text { pada } \\
\text { garis } \\
\text { bilangan } \\
\text { (pada } \\
\text { garis } \\
\text { bilangan } \\
\text { ada } \\
\text { bagian } \\
\text { yang } \\
\text { tidak } \\
\text { sama) }\end{array}$ \\
\hline $\begin{array}{l}\text { Merepresen } \\
\text { tasikan } \\
\text { pecahan } \\
\text { campuran } \\
\text { pada garis } \\
\text { bilangan }\end{array}$ & $\begin{array}{l}\text { Membagi } \\
\text { garis } \\
\text { bilangan } \\
\text { tidak } \\
\text { sesuai } \\
\text { dengan } \\
\text { konsep } \\
\text { pecahan } \\
\text { campuran } \\
\text {. Subjek } \\
\text { memaham } \\
\text { i konsep }\end{array}$ & $\begin{array}{l}\text { Membagi } \\
\text { garis } \\
\text { bilangan } \\
\text { tidak sesuai } \\
\text { dengan } \\
\text { konsep } \\
\text { pecahan } \\
\text { campuran. } \\
\text { Subjek } \\
\text { memahami } \\
\text { konsep } \\
\text { pecahan } \\
\end{array}$ \\
\hline
\end{tabular}

\begin{tabular}{|l|l|l|}
\hline & pecahan & campuran \\
& campuran & dan dapat \\
dan dapat & merepresenta \\
& mereprese & sikan dengan \\
ntasikan & gambar. \\
& dengan & \\
gambar. & \\
\hline
\end{tabular}

Menurut jenis kesalahan yang dikemukakan Hodes dan Notling (dalam Rose, 2011), kesalahan yang dilakukan subjek adalah kesalahan konseptual (conceptual errors), subjek belum memahami secara utuh tentang pecahan yang direpresentasikan pada garis bilangan. Subjek salah dalam menentukan penyebut dan pembilang terkait dengan bagianbagian yang sama pada garis bilangan. Subjek belum memahami bahwa pembilang pada garis bilangan ditunjukkan dengan menghitung banyaknya bagian dari titik nol sampai pada titik yang ditentukan. Selain itu subjek juga melakukan kesalahan aplikasi (application errors), subjek memahami konsep $\frac{7}{3}$ tetapi tidak dapat merepresentasikannya pada garis bilangan.

\section{KESIMPULAN DAN SARAN}

Berdasarkan hasil penelitian, maka dapat disimpulkan:

1. Cara subjek merepresentasi pecahan pada garis bilangan :

(a) Merepresentasikan pecahan dengan penyebut sama pada garis bilangan Subjek menghubungkan banyaknya bagian dalam 
interval 0 sampai 1 sebagai penyebut, subjek menghubungkan

banyaknya garis yang membagi antara interval 0 sampai 1 sebagai penyebut, subjek mengurutkan pecahan dari pembilang pecahan;

(b) Merepresentasikan pecahan dengan penyebut tidak sama pada garis bilangan subjek mengurutkan pecahan dengan penyebut terbesar, subjek memberi nama titik tanpa memperhatikan bagianbagiannya;

(c) Merepresentasikan pecahan pada garis bilangan pada titik yang sudah ditentukan (bagian-bagiannya sama dan bagian-bagiannya tidak sama) subjek cenderung menghitung banyaknya garis yang membagi garis bilangan menjadi beberapa bagian dari pada menghitung banyaknya bagian sama yang terbentuk untuk menjadi penyebut;

(d)Merepresentasikan pecahan campuran pada garis bilangan subjek cenderung menyamakan cara merepresentasikan pecahan campuran dengan pecahan biasa pada garis bilangan.

2. Kesalahan yang dilakukan subjek adalah kesalahan konseptual (conceptual errors), subjek belum memahami secara utuh tentang pecahan yang direpresentasikan pada garis bilangan. Selain itu subjek juga melakukan kesalahan aplikasi (application errors), subjek memahami konsep $\frac{7}{3}$ tetapi tidak dapat merepresentasikannya pada garis bilangan.

\section{DAFTAR PUSTAKA}

Battista, Michael T. 2012. Cognition-Based Assessment and Teaching of Fraction. Heinemann : Portsmouth.

Behr, Merlyn J dkk. 1984. Order and Equivalence of Rational Numbers: A Clinical Teaching Experiment. Journal for Research in Mathematics Education (Online), 15: 323-341. (http://pub.unibielefeld.de/luur/download?f unc $=$ downloadFile \&recordO $\mathrm{Id}=1781496 \&$ fileOId $=23133$ 17), diakses 7 Pebruari 2015.

Bright, George W., Behr, Merlyn.,dkk. 1988. Identifying Fractions on Number Line. Journal for Research in Mathematics Education, Vol. 19 no 3 215-232. 
Bruner, J. 1996. Towards a Theory of Instruction. Cambridge, MA : Harvard.

Carvalho, Renata. 2013. Students' Mental Computation Strategies With Fraction. Proceedings of The Eighth Congress of The European Society For Research in Mathematics Eduaction, (Online), ( http://ermeweb.free.fr/), diakses 17 Januari 2015.

Charalambous, Charalambos $\mathrm{Y}$ dan Pitta-Pantazi, Demetra. 2007. Drawing on a Theoretical Model To Study Students' Understandings of Fractions. Educational Studies in Mathematics,(Online), 64: 293-316.

(http://math.arizona.edu/ ce mela/english/content/shortco urses/assessment/Day\%202 $\% 20$ Reading\%201.pdf), diakses 16 Pebruari 2015.

Creswell, J.W. 2012. Planning, Conducting, and Evaluating Quantitave and Qualitative Research. Boston : Pearson Education.

$\begin{array}{cr}\text { Goldin, G.A. } & 2002 . \\ \text { Representation } & \text { in } \\ \text { Mathematical Learning and } \\ \text { Problem Solving. Handbook } \\ \text { of International Research in } \\ \text { Mathematics Education. }\end{array}$

Mahwah, NJ: Lawrence Erlbaum Associates, Publishers.

Hsi Wu, Hung. 2014. Teaching Fraction According to The Common Core Standars.

Janvier,C., Girardon, C., dan Morrand, J. 1993. Mathematical Symbols and Representation. Research idea for the classroom : high school mathematics. Reston, VA: National Council of Teacher of mathematics.

Kerslake, Daphne. 1986. Fraction: Children's Strategies and Errors. A Report of The Strategies and Errors in Secondary Mathematics Project. The NFER-NELSON Publishing Company Ltd. ,(Online), (http://files.eric.ed.gov/fullte xt/ED295826.pdf), diakses 16 Pebruari 2015.

Kyriakides, Andreas O. 2011. Questioning Assumptions That Limit The Learning of Fractions: The Story of Two Fifth Graders. Proceedings of The Seventh Congress of The European Society For Research in Mathematics Eduaction, (Online), ( http://ermeweb.free.fr/), diakses 17 Januari 2015. 
Mamede, Ema dan Oliveira. 2011. Issues on Children's Ideas of Fraction When Quotient Interpretation is Used. Proceedings of The Seventh Congress of The European Society For Research in Mathematics Eduaction, (Online), ( http://ermeweb.free.fr/), diakses 17 Januari 2015.

Mitchell, Annie dan Horne, Marj. 2008. Fraction Number Line and The Additivity Concept of Length Measurement. Proceeding of the $31^{\text {st }}$ Annual Conference of The Mathematics Education Research Group of Australia, (Online), 353360,

(http://www.merga.net.au/do cuments/RP412008.pdf), diakses 10 Pebruari 2015.

NCTM. 2000. Principles and Standars for School Mathematics. Reston, VA: author.

Rose, Mdaka Basani. 2011. Learners' Errors and Misconceptions Associated With Common Fraction. A mini Dissertation. University of Johannesberg, (Online), https://ujdigispace.uj.ac.za/b itstream/handle/10210/8049/ Mdaka.pdf? sequence=1), diakses 16 Pebruari 2015.
Salkind, Gwenanne M. dan Hjalmarson, Margaret. 2007. Mathematical Representation. Spring.

Skemp, R. 1986. The Psychology of Learning Mathematics. London : Penguin Books.

Wong, Monica dan Evans, David. 2007. Students' Conceptual Understanding of Equivalent Fraction. Mathematics Essential Research, (Online), Vol.2: 824-833, (http://www.merga.net.au/do cuments/RP782007.pdf), diakses 8 Pebruari 2015. 